\title{
Globe
}

Revue internationale d'études québécoises

\section{Langue, espaces et contestation}

\section{Daniel Chartier}

Volume 2, numéro 2, 1999

Les enjeux de la coexistence linguistique

URI : https://id.erudit.org/iderudit/1000465ar

DOI : https://doi.org/10.7202/1000465ar

Aller au sommaire du numéro

Éditeur(s)

Globe, Revue internationale d'études québécoises

ISSN

1481-5869 (imprimé)

1923-8231 (numérique)

Découvrir la revue

Citer ce document

Chartier, D. (1999). Langue, espaces et contestation. Globe, 2(2), 7-7.

https://doi.org/10.7202/1000465ar d'utilisation que vous pouvez consulter en ligne.

https://apropos.erudit.org/fr/usagers/politique-dutilisation/ 


\section{Présentation \\ Langue, espaces et contestation}

Pour ce quatrième numéro, la revue a invité le chercheur et spécialiste des questions linguistiques Pierre Coulombe à préparer un dossier thématique sur «les enjeux de la coexistence linguistique», auquel ont participé des auteurs du Québec, du Canada, du Royaume-Uni et de Belgique. La problématique linguistique, fondement de l'identité québécoise et prémices des débats parlementaires de l'Assemblée nationale dès ses débuts en 1792, s'inscrit dans le jeu complexe des législations fédérale et québécoise, qui parfois s'opposent et parfois se rejoignent selon les perspectives politiques.

Suit ce dossier, que présente Pierre Coulombe en introduction, un article de Tony Simons dans notre section «Études libres», qui complète le numéro et qui prolonge l'idée d'espaces coexistants, cette fois dans la trame filmique de l'œuvre la plus connue à l'étranger du cinéma québécois, Jésus de Montréal de Denys Arcand.

Daniel CHARTIER, directeur Université de La Sarre (Allemagne)

pour le conseil de rédaction, Karine Cellard, Stéphan Gervais, Peter Graefe, Pamela Lipson et Isabelle Thellen. 